\title{
Beyond Biblical Theologies
}

\author{
Hrsg. v. Heinrich Assel, Stefan Beyerle u. Christfried Böttrich
}

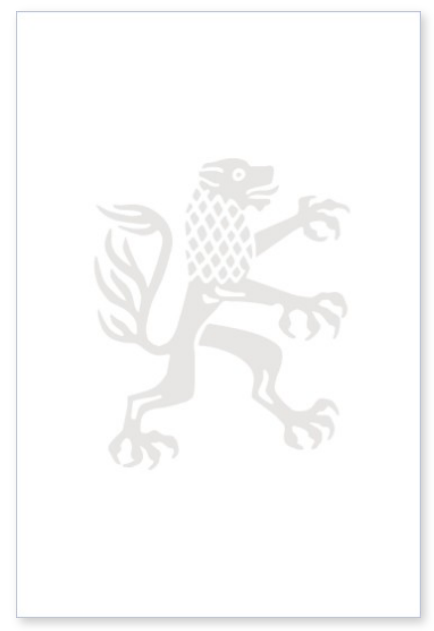

2012. X, 656 Seiten. WUNT I 295

ISBN 978-3-16-152422-6

DOI 10.1628/978-3-16-152422-6

eBook PDF $179,00 €$

ISBN 978-3-16-151001-4

Leinen $179,00 €$
Ziel des vorliegenden Sammelbandes, der die gleichnamige internationale Tagung (2009) am Krupp-Kolleg in Greifswald dokumentiert, ist die Formulierung neuer Perspektiven »Biblischer Theologien« vor dem Hintergrund bereits vorliegender Ergebnisse. Ausgangspunkte bieten die ersten Summen aus den jeweiligen theologischen Disziplinen: Altes bzw. Neues Testament und Systematische Theologie. Von hier aus behandeln die Einzelbeiträge verschiedene Fragestellungen, die sowohl Kontroversen als auch die Fundamente und Perspektiven auf Quellen jenseits des Kanons berücksichtigen. Die aus unterschiedlichen theologischen Disziplinen beigesteuerten Zugänge werden so in ein interdisziplinäres Gespräch zwischen Exegese und Systematik eingebunden und eröffnen einen nahezu enzyklopädisch-theologischen Blick auf das Thema "Biblische Theologie«. Zudem ergeben sich Leitlinien einer internationalen und generationenübergreifenden Diskussion, da sowohl etablierte und anerkannte Wissenschaftler als auch Nachwuchsforscher aus Deutschland, England, den Niederlanden, Schottland, Schweden und den USA beteiligt sind. Die Autorinnen und Autoren befassen sich mit paradigmatischen Zugängen über Quellen und konkrete Fragestellungen, aber auch mit hermeneutischen Einschätzungen und übergreifenden Themen in der aktuellen Diskussion. Schwerpunkte markieren, neben einer Psaltertheologie, Fragen der Rezeption biblischer Themen und Texte, der Gültigkeit und kerygmatischen Programmatik gesamtbiblischer Ansätze und insbesondere die Kontroversen zwischen den europäischen, vor allem deutschsprachigen, und nordamerikanischen Diskussionslagen zum Thema.

\section{Mit Beiträgen von:}

Hans-Christoph Askani, Heinrich Assel, John Barton, Stefan Beyerle, Tomas Bokedal, Christfried Böttrich, John J. Collins, Michael Coors, Beate Ego, Gösta Hallonsten, Eva Harasta, Joel S. Kaminsky, Corinna Körting, Ulrike Mittmann, Georg Pfleiderer, Enno Edzard Popkes, Anathea Portier-Young, Ferdinand R. Prostmeier, Gregor Reichenbach, Eckart David Schmidt, Stefan Schorch, Rudolf Smend, Philipp Stoellger, Jaques van Ruiten, Petra von Gemünden, Michael Welker.

Inhaltsübersicht

\section{Heinrich Assel / Stefan Beyerle / Christfried Böttrich: Vorwort}

I. Forschungsperspektiven und Zugänge / History of Scholarship and Basic Approaches Rudolf Smend: Der Greifswalder Julius Wellhausen und die Biblische Theologie - Stefan Beyerle: »Beyond« Grenzbeschreibungen zur Biblischen Theologie - Christfried Böttrich: Der Raum zwischen den Testamenten - Heinrich Assel: Den Text der Menschwerdung lesen lernen. Das Fiktive und das Imaginäre in Joh 1 als Aufgabe der Inkarnationschristologie

II. Kontroversen / Controversies

Gösta Hallonsten: Joseph Ratzingers/Benedikts XVI. 'Jesus von Nazareth': spirituelle Auslegung und kritische Anfragen - Georg Pfleiderer: Ausbruchsversuche aus der Moderne. Zur Problematik der kerygmatischen Programmatik Biblischer Theologie Ulrike Mittmann: Die neutestamentliche Rezeption von Ps 2 und Ps 110 (109 LXX) als Prüfstein einer gesamtbiblischen Hermeneutik und Exegese. Hartmut Geses traditionsgeschichtlicher Ansatz in der Diskussion - John J. Collins: Biblical Theology Between Apologetics and Criticism - John Barton: (Pan-)Biblical Theology in the German- and English-speaking Worlds: A Comparison

III. Fundamente / Fundaments

1. Namen und Gültigkeit / Names and Validity

Tomas Bokedal: Notes on the Nomina Sacra and Biblical Interpretation - Gregor Reichenbach: Zur Gültigkeit biblischer Texte

2. Der Psalter als »Kleine Biblia« / Psalms as »Kleine Biblia«

Corinne Körting: Israel und die Völker im Lobpreis. Ein Beitrag zur Theologie der Hebräischen Bibel und zur Biblischen Theologie - Eva Harasta: Between Prayer and Action: Psalm 22 as Orientation and Formation of Dogmatic Thinking

3. Der Text als Fundament Biblischer Theologie / Text as Fundament of a Biblical Theology

Michae/ Coors: The Fragmentation of Theology at the Limit of the Text The Theological Reading of the Bible Beyond Biblical Theologies in the Works of Karl Barth and Johann Andreas Quenstedt - Stefan Schorch: Which Bible, Whose Text? Biblical Theologies in Light of the Textual History of the Hebrew Bible

4. Themen und Motive / Themes and Motifs

Joel S. Kaminsky: The Hebrew Bible's Theology of Election and the Problem of Universalism - Anathea Portier-Young: Drinking the Cup of Horror and Gnawing on Its Shards: Biblical Theology Through Biblical Violence, Not Around It - Eckart David Schmidt: Heiligung: Implikationen in 2Thess im Anschluss and 1Thess

5. Theologische Paradigmen / Theological Paradigms

Hans-Christoph Askani: Zeugnis ohne Ende? Zur Konfiguration von Gabe, Zeugnis und Stil - Philipp Stoellger: Biblische Theologie - in bildtheoretischer Perspektive: 'Bild' als Beispiel einer Hermeneutik der Differenz - Michael Welker: Theological Realism and Biblical Theology

IV. Perspektiven jenseits des Kanons / Perspectives Beyond the Canon

Petra von Gemünden: Die Fremdheit der Bibel wahrnehmen - der kulturanthropologische Beitrag zur Exegese - Beate Ego: Abrahams Jugendgeschichte in der Literatur des frühen Judentums - Ein Paradigma theologischer Rezeptionskonzepte in der 
Antike - Jacques T.A.G.M. Van Ruiten: The Book of Jubilees and the Genesis Apocryphon as Examples of the Rewriting of Authoritative Texts in Early Judaism: The Case of Abram and Sarai's Stay in Egypt (Gen 12:9-13:4) - Ferdinand R. Prostmeier: Einfache Wahrheit? Schrift und christliche Theologie im zweiten Jahrhundert - Enno Edzard Popkes: The Gospel of Thomas within Early Christian History: A Theological Appreciation and Discussion

Heinrich Assel Geboren 1961; 1993 Promotion; 1999 Habilitation; 1999-2006 Professur für Systematische Theologie an der Kulturwissenschaftlich-Philologischen Fakultät der Universität Koblenz-Landau; seit 2006 Lehrstuhl für Systematische Theologie an der Theologischen Fakultät der Universität Greifswald; 2020-22 Dekan der Fakultät. https://orcid.org/0000-0001-6248-2795

Stefan Beyerle ist Professor für Altes Testament an der Ernst-Moritz-Arndt-Universität Greifswald.

Christfried Böttrich ist Professor für Neues Testament an der Ernst-Moritz-Arndt-Universität Greifswald.

Jetzt bestellen:

https://mohrsiebeck.com/buch/beyond-biblical-theologies-9783161524226?no_cache=1

order@mohrsiebeck.com

Telefon: +49 (0)7071-923-17

Telefax: +49 (0)7071-51104 